\title{
Psychological, physiological and behavioural responses of tourists to interactions with rhesus macaques at $\mathrm{Zhangjiajie,} \mathrm{China.}$
}

Junnian Li*, Shuanglun Tao, Dongmei Yang, Lan He, Lu Zeng, Ralf Buckley ${ }^{+}$

College of Biological Resources and Environmental Science, Jishou University, Jishou 416000, China. ${ }^{+}$International Centre for Ecotourism Research, Griffith University, Australia 4222.

*Corresponding author: College of Biological Resources and Environmental Science, Jishou University, Jishou 416000, China. Tel: +86 743 2142226; Fax: +86 743 8565323; Email address junnian1@163.com

\section{Abstract}

We compared gait, pulse, blood pressure and speech volume of tourists before and after encounters with rhesus macaques, Macaca mulata, in Zhangjiajie National Forest Park, China, relative to a control site without macaques. We tested 600 tourists from 38 groups, stratified by age and gender. We also compared length of stay and number of photographs at each site, and elicited tourists' views and emotions through a questionnaire. Behavioural, physiological and psychological indicators all showed positive responses to interactions with macaques. Few previous studies of wildlife tourism have measured human responses in this way.

\section{Introduction}

Wildlife tourism is a major component of the trillion-dollar global outdoor tourism sector (Buckley, 2009; Jiang, 2001; Liu, Pan, Zhong, \& Jin, 2006; Newsome, Dowling, \& Moore, 2005). Models of wildlife tourism, however, remain incomplete (Buckley \& Castley, 2012). There is extensive research on: the impacts of tourism and recreation on wildlife (Buckley, $2004,2011,2012)$ and the role and value of tourism in contributing to wildlife conservation (Buckley, 2010, 2012). There is also an extensive but largely unrelated literature on the beneficial human health interactions with captive and companion animals, including zoos, pets, and farm and working animals (Gillum \& Obisesan, 2011; Herzog, 2012; Wells, 2009). There is much less research on the impacts on humans of interacting with wild animals. 
One wildlife tourism subsector of particular human psychological interest involves interactions with apes and monkeys, because of their perceived similarities in behaviour and expressions (Fuentes, 2006). Many commercial wildlife tours are focused on these species. Examples include orang-utan in Borneo, and gorillas and chimpanzees in Africa (Adams \& Infield, 2003). Macaques in particular form a widespread attraction in many protected areas in southern Asia (Agoramoorthy \& Hsu, 2006; Hsu, Kao, \& Agoramoorthy, 2009; Sha et al., 2009).

\section{Study Site and Methods}

Zhangjiajie National Forest Park in Hunan Province of southern China is $9563 \mathrm{~km}^{2}$ in area and was established in 1982. With mean annual rainfall of $1400 \mathrm{~mm}$, it supports subtropical monsoon forest on lowland areas. There are 22 known populations of rhesus macaques in the Park, around 1400 individuals in all. One of the Park's principal scenic points, an area known as Golden Whip River (金鞭溪, Jin Bian), supports a resident macaque population which is visited frequently by tourists. As a control site we selected an otherwise similar area with no macaques, known as Supernal Hawk Protecting Whip (神鹰护鞭, Shen Ying Hu Bian).

We constructed a stratified random sample of 600 tourists selected from 38 tourist groups. The overall sample included 100 men, and 100 women, in each of the three age groups 15-25, 26-65 and over 65 respectively. Each tourist was observed for $\sim 6$ days. Because of the layout of the park, all tourists visited both the control and the experimental site. We recorded how long each tourist spent at the control and experimental sites, and how many photographs they took at each. We measured speech volume (dB) using a Lisheng Hs5660A sound meter, and pulse and blood pressure before and after watching the macaques, using a Yuyue GB4227-84 blood pressure meter. Using remote digital cameras $20 \mathrm{~m}$ from walking tracks, we photographed each tourist every $10 \mathrm{~cm}$ along the track so as to calculate length and frequency of steps, before and after interactions with the macaques. 


\section{Results}

Both the length and frequency of steps increased significantly (t-test, $\mathrm{p}<0.01)$ after interacting with the macaques, for female tourists in all three age groups and male tourists $>65$ years old (Table 1). There were no significant changes in gait for younger and middle-aged males. Blood pressure, both diastolic and systolic, increased for all ages and both genders, and pulse rates increased for all female tourists and for younger and middle-aged males $(\mathrm{p}<0.01$ in each case) (Table 2). Tourists stayed much longer and spoke much more loudly at the macaque site than the control site $(\mathrm{p}<0.01$ in each case) (Table 3). Over three quarters $(78 \%)$ of tourists took photographs of the macaque site, but fewer than half (49\%) at the control site. Most $(78 \%)$ of the tourists played directly with the macaques. When asked via the questionnaire surveys, $63 \%$ said they liked the macaques very much, $86 \%$ expected to play with wildlife, $69 \%$ thought scenic areas should stock native wildlife, and 92\% displayed a cheerful expression.

\section{Conclusions}

Psychological, physiological and behavioural measures all indicate that tourists respond enthusiastically to interacting with wild but habituated macaques at Zhangjiajie. Their responses demonstrate increased arousal, through increased photographic activity, a livelier gait, louder speech, and increased pulse rate and blood pressure. Their responses also demonstrate positive valence, through longer stays, cheerful expressions, and direct spoken responses to interview questions. There are some differences between age groups and genders, but these are secondary, and may be due to other aspects of behaviour such as taking intermittent rests whilst walking. The positive reactions also reflect the behaviour of the macaques at this site, which are friendly to tourists and do not attack them. Similar positive effects on tourists attitudes are reported by Waylen, McGowan, Group and Milner-Gullard (2009). This contrasts with reports for some other species, and indeed for macaques at some other sites, where interactions can become negative, eg if wild animals approach tourists aggressively in search of food (Buckley, 2004; Hsu et al., 2009; Sha et al., 2009).

The results reported here reflect several subtle cultural differences between Western concepts of ecotourism, and its Chinese analogue shengtai luyou (Buckley, Zhong, Cater \& Chen, 2008). Chinese cultural traditions do not draw such an emphatic distinction between humans 
and nature as occurs in the West, and in consequence, are much more accepting of anthropogenic modifications to natural protected areas. In this research, for example, respondents thought that scenic areas should stock wildlife. Not only would this response be unusual in Western national parks, but it would be unusual for researchers to ask such a question. One of the key differences between these concepts is that shengtai luyou incorporates a focus on human health benefits. The broad long-term positive effects on human health from outdoor recreation and nature-related experiences have indeed been promoted extensively in Western nations. Detailed measurements of changes in coupled psychological, physiological and behavioural indicators as a result of direct interactions with wildlife, however, such as those reported here, do not seem to have been reported. They deserve further attention.

\section{Acknowledgements}

We thank the staff of Zhangjiajie National Forest Park for their generous assistance in the field. This research was funded by: the National Natural Science Foundation of China, Project 30570285; the National Basic Research Program of China, Project 2007CB109102; and Hunan Provincial Key Laboratory of Ecotourism and Applied Technology, Project JDSTLY201102. Fieldwork by JL, ST, DY, LH \& LZ; writing by JL \& RB. 


\section{References}

Adams, W.M., \& Infield, M. (2003). Who is on the gorilla's payroll? Claims on tourist revenue from Ugandan National Park. World Development, 31, 177-190.

Agoramoorthy, G., \& Hsu. M.J. (2006). Population status of long tail macaques (Macaca fascicularis) in Singapore. Mammalian, 70, 300-302.

Buckley, R.C. (2004). Impacts of ecotourism on terrestrial wildlife. In: R.C. Buckley (Ed.) Environmental impacts of ecotourism (pp. 211-228). Wallingford: CAB International.

Buckley, R.C. (2009). Ecotourism: Principles and practices. Wallingford: CAB International.

Buckley, R.C. (2010). Conservation tourism. Wallingford: CAB International.

Buckley, R.C. (2011). Tourism and environment. Annual Review of Environment and Resources, 36, 397-416.

Buckley, RC. (2012). Sustainable tourism: research and reality. Annals of Tourism Research

Buckley, R.C., \& Castley, J. Guy. Models of wildlife tourism. Biological Conservation (in press).

Buckley, R.C., Zhong, L.S., Cater, C., and Chen, T. 2008. Shengtai luyou: cross-cultural comparison in ecotourism. Annals of Tourism Research, 25, 945-968.

Fuentes, A (2006). Human culture and monkey behaviour: Assessing the contexts of potential pathogen transmission between macaques and humans. American Journal of Primatology, 68, 880-896.

Gillum, R.F., \& Obisesan, T.O. (2010). Living with companion animals, physical activity and mortality in a US national cohort. International Journal of Environmental Research and 
Public Health, 7, 2452-2459.

Herzog, H. (2011). The impact of pets on human health and psychological well-being : fact, fiction, or hypothesis? Current Directions in Psychological Science, 20, 236-239.

Hsu, M.J., Kao, C.C., \& Agoramoorthy, G. (2009). Interactions between visitors and Formosan macaques (Macaca cyclopis) at Shou-Shan Nature Park, Taiwan. American Journal of Primatology, 71, 214-222.

Jiang, Z.G. (2001). Values and ecological service functions of wildlife. Acta Ecologica Sinica, 21(11), 1909-1917.

Liu, Y.P., Pan, X.F., Zhong, Q.P., \& Jin, J.X. (2006). Analyzing about the assessment of the recreational value of the natural spaces in ecotourism districts: Applying contingent valuation method and travel cost method to analyze the recreational value of $\mathrm{Wu}$ ling yuan Scenic Resort. Acta Ecological Sinica, 26(1), 3765-3774.

Newsome, D., Dowling, R., \& Moore, S. (2005) Wildlife Tourism. Clevedon: Channel View.

Sha, J.C.M., Gumert, M.D., Lee, B.P.Y-H., Jones-Engel, L., Chan, S., \& Fuentes, A. (2009). Macaque-human interactions and the societal perceptions of macaques in Singapore. American Journal of Primatology, 71, 825-839.

Waylen, K.A., McGowan, P.J.K., Group, P.S., \& Milner-Gulland, E.J. (2009). Ecotourism positively affects awareness and attitudes but not conservation behaviours: A case study at Grande Riviere, Trinidad. Oryx, 43, 343- 352.

Wells, D.L. (2009). The effects of animals on human health and well-being. Journal of Social Issues, 65, 523-543. 
Table 1a. Step frequency before and after interactions with macaques

\begin{tabular}{llll}
\hline Gender & Age & Before & After \\
\hline Male & $15-25$ & $119.36 \pm 9.71$ & $124.15 \pm 7.10$ \\
Male & $26-65$ & $105.34 \pm 8.22$ & $109 . .42 \pm 4.39^{* *}$ \\
Male & $>65$ & $84.57 \pm 7.42$ & $103.29 \pm 5.77^{*}$ \\
Female & $15-25$ & $94.37 \pm 2.96$ & $112.61 \pm 5.58^{* *}$ \\
Female, & $26-65$ & $99.77 \pm 5.14$ & $105.28 \pm 4.91^{*}$ \\
& & & \\
Female & $>65$ & $80.22 \pm 3.57$ & $108.32 \pm 4.81^{* *}$ \\
\hline
\end{tabular}

$*, \mathrm{p}<0.05, * *, \mathrm{p}<0.04$

Table 1b. Step length before and after interactions with macaques

\begin{tabular}{llll}
\hline Gender & Age & Before & After \\
\hline Male & $15-25$ & $0.722 \pm 0.015$ & $0.793 \pm 0.021$ \\
Male & $26-65$ & $0.717 \pm 0.017$ & $0.721 \pm 0.017$ \\
Male & $>65$ & $0.611 \pm 0.006$ & $0.645 \pm 0.029^{*}$ \\
Female & $15-25$ & $0.652 \pm 0.013$ & $0.672 \pm 0.029^{* *}$ \\
Female, & $26-65$ & $0.636 \pm 0.022$ & $0.712 \pm 0.018^{*}$ \\
Female & $>65$ & $0.52 \pm 0.013$ & $0.54 \pm 0.013^{* *}$ \\
& & & \\
\hline
\end{tabular}

$*, \mathrm{p}<0.05, * *, \mathrm{p}<0.01$ 
Table 2a. Diastolic blood pressure before and after interaction with macaques

\begin{tabular}{llll}
\hline Gender & Age & Before & After \\
\hline Male & $15-25$ & $68.5 \pm 1.17$ & $71.8 \pm 1.50$ \\
Male & $26-65$ & $72.3 \pm 2.37$ & $76.5 \pm 2.93$ \\
Male & $>65$ & $74 \pm 4.89$ & $83 \pm 4.98^{* *}$ \\
Female & $15-25$ & $63.3 \pm 2.28$ & $69.9 \pm 5.55^{*}$ \\
Female & $26-65$ & $61 \pm 2.05$ & $73 \pm 2.38^{* *}$ \\
Female & $>65$ & $59.8 \pm 2.23$ & $63.9 \pm 1.98^{* *}$ \\
\hline
\end{tabular}

$*, \mathrm{p}<0.05, * *, \mathrm{p}<0.01$

Table 2b. Systolic blood pressure before and after interaction with macaques

\begin{tabular}{llll}
\hline Gender & Age & Before & After \\
\hline Male & $15-25$ & $107 \pm 1.61$ & $116.8 \pm 2.08^{* *}$ \\
Male & $26-65$ & $107 \pm 1.79$ & $117 \pm 1.31^{* *}$ \\
Male & $>65$ & $110 \pm 3.51$ & $125 \pm 3.04^{* *}$ \\
Female & $15-25$ & $104.7 \pm 2.45$ & $114.9 \pm 1.88^{* *}$ \\
Female & $26-65$ & $101 \pm 2.58$ & $112.1 \pm 3.06^{* *}$ \\
Female & $>65$ & $98 \pm 3.62$ & $105.7 \pm 3.34^{* *}$ \\
\hline
\end{tabular}

$*, \mathrm{p}<0.05, * *, \mathrm{p}<0.01$ 
Table 2c. Pulse rates before and after interaction with macaques

\begin{tabular}{llll}
\hline Gender & Age & Before & \multicolumn{1}{l}{ After } \\
\hline Male & $15-25$ & $62.6 \pm 2.32$ & $63.9 \pm 2.28$ \\
Male & $26-65$ & $63.6 \pm 2.68$ & $69.4 \pm 2.37$ \\
Male & $>65$ & $72.8 \pm 2.11$ & $80.6 \pm 2.64^{* *}$ \\
Female & $15-25$ & $70.0 \pm 2.76$ & $72.1 \pm 2.84$ \\
Female & $26-65$ & $70.4 \pm 3.72$ & $72.5 \pm 4.07$ \\
Female & $>65$ & $68.9 \pm 2.32$ & $70.1 \pm 1.90$ \\
\hline
\end{tabular}

$*, \mathrm{p}<0.05, * *, \mathrm{p}<0.01$ 
Table 3. Differences in tourist behaviour between control and experimental sites.

\begin{tabular}{llllll}
\hline Site & $\begin{array}{l}\text { Sound } \\
\text { volume, dB }\end{array}$ & $\begin{array}{l}\text { Length of stay, } \\
\text { minutes }\end{array}$ & $\begin{array}{l}\% \text { taking } \\
\text { photos }\end{array}$ & $\begin{array}{l}\text { No. of } \\
\text { photos }\end{array}$ & $\begin{array}{l}\text { Playing with } \\
\text { macaques, } \%\end{array}$ \\
\hline Experimental & $74.65 \pm 0.91$ & $219.60 \pm 13.41$ & 48.75 & 353 & 0 \\
Control & $91.30 \pm 1.49^{* *}$ & $651.21 \pm 31.78^{* *}$ & 78.12 & 723 & 78.56 \\
\hline
\end{tabular}

*, $\mathrm{p}<0.05 ; * *, \mathrm{p}<0.01$ 